\title{
KOMPARASI TEORI KEBENARAN \\ MO TZU DAN PANCASILA: \\ RELEVANSI BAGI PENGEMBANGAN \\ ILMU PENGETAHUAN DI INDONESIA
}

\section{Budisutrisna}

Fakultas Filsafat, Universitas Gadjah Mada, Yogyakarta

Email: budisutrisna@ugm.ac.id

\section{Abstrak}

Teori kebenaran Mo Tzu dan teori kebenaran Pancasila kedua-duanya menggunakan tiga paham kebenaran, yakni: koherensi, korespondensi, dan paragmatik. Namun demikian kedua teori kebenaran tersebut perlu dikomparasikan. Perlu dicari kesamaannya dan perbedaannya. Kemudian dicari relevansinya bagi pengembangan ilmu pengetahuan di Indonesia sebagai negara yang berdasarkan Pancasila. Penelitian ini merupakan penelitian kepustakaan. Metode yang dipergunakan dalam penelitian ini adalah metode hermeneutik filosofis, dengan unsur-unsur: deskripsi, kesinambungan historis, komparasi, dan refleksi. Hasil penelitian menunjukkan bahwa ada beberapa kesamaan dan perbedaan antara teori kebenaran Mo Tzu dan Pancasila. Relevansi bagi pengembangan ilmu di Indonesia, bahwa kebenaran harus koheren dengan nilai-nilai Pancasila, harus sesuai dengan kenyataan adanya Tuhan, manusia, satu, rakyat, dan adil. Di samping itu kebenaran harus berfaedah bagi kemanusiaan yang berketuhanan, berpersatuan, berkerakyatan, dan berkeadilan.

Kata kunci: teori kebenaran Mo Tzu, teori kebenaran Pancasila, pengembangan ilmu.

\section{Abstract}

Mo Tzu's theory of truth and the truth of the theory of Pancasila both using three understand the truth, namely: coherence, correspondence, and paragmatik. However, both theories are necessary dikomparasikan truth. Necessary to find similarities and differences. Then look for relevance to the development of science in Indonesia as a country based on Pancasila. This study is a literature. The method used in this research is a philosophical hermeneutic method, with the following elements: description, historical continuity, comparison and reflection. The results showed that there are some similarities and differences between the theory of truth Mo Tzu and Pancasila. Relevance to the development of science in Indonesia, that the truth must be coherent with the values of 
Pancasila, should correspond to the reality of God, man, one, people, and fair. In addition, the truth must be beneficial for humanity which believes God, keeps unitary, democratic, and justice.

Keywords: Mo Tzu's theory of truth, the truth of the theory of Pancasila, the development of science.

\section{PENDAHULUAN}

Setiap ilmuwan memiliki kewajiban untuk mengarahkan segenap kegiatan ilmiahnya sampai pada tujuan umum yang hendak dicapai oleh setiap ilmu pengetahuan. Tujuan tersebut adalah untuk memperoleh kebenaran ilmiah dan sedapat mungkin juga untuk mencapai atau meningkatkan kebahagiaan umat manusia.

Dalam kaitannya dengan pengembangan ilmu di Indonesia, maka perlu dikaji kebenaran yang khas menurut Pancasila terlebih dahulu. Sebab Pancasila sebagai pandangan hidup dan dasar negara akan selalu menjadi ukuran bagi setiap sikap dan perbuatan termasuk kegiatan para ilmuwan dengan produkilmu pengetahuannya.

Mengenai masalah kebenaran, sejak dahulu selalu menyertai setiap kegiatan ilmiah. Hal yang demikian ini karena pada ilmu pengetahuan, baik sebagai suatu sistem maupun proses senantiasa ditujukan untuk mencapai kebenaran. Secara historis dapat diketahui, bahwa dalam hal kebenaran sudah ada tiga paham tradisional yang besar yaitu paham koherensi, korespondensi, dan pragmatik. Tetapi timbul masalah lain, yaitu seandainya hendak berpikir secara sistematik sekaligus sintetik, maka kiranya ketiga macam paham tersebut dapat dipadukan dalam suatu kerangka yang seluas-luasnya. Sehingga diharapkan dapat merangkum segenap paham-paham yang lain (Soejono Soemargono, 1983a:1).

Di Cina ada seorang Filsuf bernama Mo Tzu pernah memadukan ketiga paham tersebut dalam pemikiran filsafatnya. Maka kiranya teori kebenaran Mo Tzu perlu dikomparasikan dengan teori kebenaran Pancasila. Hal yang demikian ini perlu dilakukan guna merumuskan suatu teori kebenara yang memiliki relevansi bagi pengembangan ilmu pengetahuan di Indonesia. 


\section{TEORI-TEORI KEBENARAN}

Sejak dahulu sesungguhnya masalah kebenaran senantiasa selalu menyertai setiap kegiatan ilmiah. Hal ini karena apa yang dinamakan ilmu pengetahuan baik sebagai suatu sistem maupun sebagai proses kegiatan manusia senantiasa ditujukan untuk mencapai kebenaran. Jika diperhatikan maka hal-hal yang hendak dibahas dalam epistemologi antara lain adalah tentang terjadinya pengetahuan, sumber pengetahuan, asal mula pengetahuan, batas-batas pengetahuan, sifat pengetahuan, metode atau cara memperoleh pengetahuan, kesahihan (validity) pengetahuan, dan kebenaran pengetahuan (Abbas H.M., 1983: 16). Semakin jelas bahwa kebenaran merupakan salah satu hal yang selalu ingin dicari dalam dunia ilmu pengetahuan, selain ilmu pengetahuan juga sedapat mungkin untuk mencapai atau meningkatkan kebahagiaan umat manusia.

Bahwa kebenaran merupakan salah satu permasalahan dalam epistemologi juga dinyatakan oleh Sidi Gazalba. Menurutnya permasalahan yang hendak diselesaikan epistemologi adalah sebagai berikut:

“Apakah sumber pengetahuan itu dunia dalam kita (subjek) atau dunia luar?

Sampai di manakah benar dan berlakunya pengetahuan itu?

Sampai di mana batas pengetahuan?

Apa hakikat pengetahuan?

Bagaimana membentuk pengetahuan yang benar?

Dapatkah manusia mencapai kebenaran?

Apakah kebenaran itu?

Permasalahan tersebut dengan aspeknya yang beragam dapat disarikan dalam dua masalah pokok, yaitu sumber pengetahuan dan berlaku atau benarnya pengetahuan" (SidiGazalba, 1981:118-119).

Dengan demikian, masalah kebenaran selalu mewarnai dinamika pengetahuan. Tentang masalah kebenaran, dapat ditinjau secara ob- 
jektivistik, kebenaran itu merupakan suatu keadaan yang menunjukkan adanya kesesuaian antara isi pikiran manusia tentang suatu objek tertentu dengan kenyataan yang sesungguhnya dari objek itu. Jika ditinjau secara subjektivistik, kebenaran itu merupakan suatu proses yang menggambarkan mengenai adanya keruntutan antara cara/jalan berpikir manusia tentang suatu objek tertentu. Selain itu juga ditinjau secara subjektivistik, khususnya ditinjau secara subjektivistik-pragmatik, kebenaran itu merupakan sebuah proses yang menggambarkan bahwa pemikiran manusia mengenai suatu objek tertentu dapat diambil manfaatnya bagi penyelesaian sesuatu masalah hidup. Dengan demikian berarti jika berbicara mengenai masalah kebenaran setidaknya didapati tiga macam pengertian yang dikandung oleh istilah tersebut, yaitu kebenaran teoritik-objektivistik, kebenaran teoritik-subjektivistik, dan kebenaran pragmatik-subjektivistik (Soejono Soemargono, 1983b: 13).

Dari uraian tersebut dapatlah dikatakan bahwa setiap langkah manusia dalam kehidupan sehari-hari dalam tingkatan pertama sudah mempunyai landasan yang bersifat teoritik-subjektivistik, dan dalam tahapan yang tertinggi masih pula dilandasi oleh suatu pemikiran yang bersifat teoritik-objektivistik. Dalam kaitannya dengan masalah kebenaran, pada dasarnya ada tiga macam teori, yaitu teori kebenaran koherensi, teori kebenaran korespondensi, dan teori kebenaran pragmatik.

Teori kebenaran koherensi mengatakan bahwa kebenaran itu merupakan suatu proses atau suatu hasil proses atau keadaan yang menunjukkan adanya keadaan yang runtut, yang masuk akal, yang saling berhubungan antara gagasan-gagasan yang dimiliki oleh seorang subjek mengenai suatu objek tertentu. Dengan perkataan lain jika orang mengatakan bahwa suatu pendapat mengenai sesuatu hal itu benar, maka ciri-ciri pokoknya dari pendapat semacam itu ialah harus bersifat runtut, harus masuk akal dan gagasan-gagasan yang mendukungnya harus saling berhubungan. Harus bersifat runtut, karena di antara gagasan yang mendukung pendapat yang bersangkutan tidak boleh menjadi suatu pertentangan. Harus bersifat masuk akal atau 
logis, karena penalarannya harus didasarkan secara ketat atas hukumhukum berpikir, seperti yang diajarkan dalam logika. Dikatakan harus koheren, karena di antara gagasan-gagasan tersebut bukan hanya harus terdapat suatu keadaan yang bersifat saling berhubungan secara fungsional (Soejono Soemargono, 1983b: 14).

Mengenai teori kebenaran korespondensi, rumusnya bermula dari Aristoteles. Ia menyebutnya sebagai teori penggambaran. Definisi kebenaran menurutnya adalah penyesuaian antara pikiran dengan kenyataan (Endang Saifudin Anshori, 1987: 22). Bagi teori kebenaran korespondensi, suatu proposisi bernilai benar jika materi pengetahuan yang terkandung dalam proposisi tersebut berkesesuaian atau koresponden dengan objek yang dituju. Dalam teori kebenaran hal ini dikenal dengan proposisi dan kenyataan. Kebenaran adalah kesesuaian antara proposisi dengan kenyataan.

Mengenai teori kebenaran pragmatik, para penganutnya berpendapat bahwa kebenaran suatu proposisi diukur dengan kriteria apakah proposisi tersebut berfungsi bagi kehidupan praktis atau tidak. Menurut William James (1824-1910) sebagai salah seorang tokoh pragmatisme, proposisi "Tuhan ada" bernilai benar bagi seseorang yang hidupnya mengalami perubahan karena percaya terhadap adanya Tuhan (Van Peursen, 1983: 34).

Teori kebenaran pragmatik mengatakan bahwa kebenaran itu merupakan suatu proses atau keadaan yang menunjukkan bahwa pikiran seseorang mengenai objek tertentu tidaklah bersifat tidak memihak begitu saja atau tidak bersifat netral dan bahkan tidak sekedar menunjukkan keruntutan, sifat masuk akal atau koherensi di antara gagasan-gagasan yang mendukung pendapat yang bersangkutan. Tetapi pikiran tersebut haruslah dalam babak terakhir dan dalam kenyataannya dapat menghasilkan manfaat bagi manusia dalam menyelesaikan masalah-masalah hidupnya (Soejono Soemargono, 1983a: 1).

Peirce (1839-1919) dalam kaitannya dengan teori kebenaran pragmatik menyatakan bahwa yang penting adalah pengaruh sebuah ide dalam rencana tindakan, bukan apa itu ide pada hakikatnya. Nilai suatu pengertian tergantung pada peranannya yang nyata dalam masya- 
rakat. Pengetahuan adalah benar jika dapat membuktikan manfaatnya kepada masyarakat (Van Peursen, 1983: 34). Kemudian teori kebenaran pragmatik ini dikembangkan oleh ahli-ahli pikir yang sebagian besar berkebangsaan Amerika.

Ketiga teori tentang kebenaran telah dikemukakan. Tetapi apabila ketiga teori tersebut dipersatukan secara harmonis, maka dapatlah dikatakan bahwa kebenaran itu merupakan suatu keadaan, suatu proses atau hasil proses yang sedapat mungkin menunjukkan kesesuaian antara pikiran manusia mengenai sesuatu objek tertentu dengan keadaan yang senyatanya dari objek tersebut. Selain itu pikiran juga sedapat mungkin memberikan manfaat bagi penyelesaian masalahmasalah hidup sehari-hari. Namun, bagaimanapun juga pikiran tadi haruslah bersifat runtut, masuk akal, dan bagian-bagiannya saling berhubungan (Soejono Soemargono, 1983a: 1). Dengan demikian, jelaslah bahwa ketiga teori tersebut dalam kehidupan manusia sehari-hari seharusnya tidak dipertentangkan, melainkan saling melengkapi.

\section{TEORI KEBENARAN MO TZU (479-381 SEBELUM M)}

Mo Tzu adalah salah seorang filsuf Cina yang hidup antara rentang waktu 479-381 sebelum Masehi. Bagi Mo Tzu membangun masyarakat tidak cukup dengan ucapan-ucapan tentang teori-teori kenegaraan, melainkan juga pelaksanaannya. Mo Tzu mengajukan prinsip kasih semesta atau Chien ai (universal love) yang sekaligus juga dilaksanakan dalam kehidupan sehari-hari, selain itu ia juga seorang ahli pertahanan. Sebagai contoh ketika Mo Tzu menjadi pejabat negara Sung, negara ini akan diserang negara lain. Sebagai ahli pertahanan, ia mendatangi negara itu dengan alsan untuk membujuk pejabat negara itu agar tidak melakukan penyerbuan ke negara Sung. Sebelumnya Mo Tzu telah menciptakan senjata khusus dan melatih murid-muridnya untuk mempertahankan negara Sung apabila bujukan gagal (Cheng, 1947: 110). Selain itu Mo Tzu tidak hanya memberikan konsep kebenaran. Tetapi konsep kebenaran yang diberikannya dipraktekkan dalam filsafatnya, guna memperkuat filsafatnya dan sekaligus juga dilaksanakan dalam kehidupan sehari-hari. Oleh karena itu dalam memaparkan 
konsep kebenaran ini, juga sekaligus akan diberikan contoh-contoh dalam filsafatnya dan praktek-praktek dalam kehidupannya. Berikut ini akan diuraikan dasar kebenaran, prinsip verifikasi, dan sifat kegunaan sebagai kriteria kebenaran yang dikemukakan Mo Tzu.

1. Dasarkebenaran

Suatu ajaran atau pendapat bernilai benar jika mempunyai dasar yang kuat. Dasar itu diperoleh dari atas yaitu Tuhan dan roh-roh serta pendapat dan perbuatan maupun ucapan-ucapan raja bijaksana zaman dahulu yang telah terbukti dapat mendatangkan kemanfaatan yang besar bagi rakyatnya. Suatu ajaran atau pendapat yang mempunyai dasar pada kehendak Tuhan, roh-roh dan perbuatan raja bijaksana zaman dahulu akan mempunyai dasar kebenaran yang kuat. Raja bijaksana zaman dahulu selalu mendasarkan ajarannya kepada kehendak Tuhan, roh-roh dan raja bijaksana sebelumnya.

Untuk memperkuat pendapat-pendapatnya, terutama mengenai kasih semesta, Mo Tzu mencontoh perbuatan-perbuatan dan pendapat-pendapat raja zaman dahulu. Ajaran Mo Tzu harus dilaksanakan karena raja zaman dahulu telah melaksanakan dan memperoleh hasil yang menguntungkan rakyat. Suatu pendapat bernilai benar kalau dapat menunjukkan dasarnya. Dalam kaitannya dengan dasar kebenaran ini Mo Tzu berkata sebagaimana dikutip oleh Creel sebagai berikut:

"Saya telah menentukan bahwa sesuatu yang paling benar diperbuat adalah menyesuaikan diri dengan jalan yang telah ditempuh oleh raja-raja bijaksana zaman dahulu, mencari pengertian-pengertiannya dan menguji perbuatanperbuatan orang ke dalam ucapan-ucapan orang bijaksana zaman dahulu" (Creel,1953: 63).

Suatu perbuatan, pernyataan, dan ucapan dianggap benar jika koheren dengan pernyataan dan perbuatan-perbuatan raja bijaksana zaman dahulu yang dianggap benar. Sesuatu yang paling benar adalah kesesuaiannya dengan jalan yang telah ditempuh oleh raja-raja bijaksana zaman dahulu, mencari pengertian-pengertiannya dan menguji perbuatan-perbuatan orang ke dalam ucapan-ucapan orang bijaksana 
zaman dahulu (Creel, 1953:492). Jelaslah bahwa suatu kebenaran harus mempunyai kesesuaian dengan dasarnya.

Prinsip ketaatan kepada atasan dapat diterapkan di mana saja. Prinsip ini dapat dilaksanakan di dalam pemerintahan negara sampai dengan pengaturan rumah tangga untuk memperoleh ketertiban (Chan, 1973: 230). Sesuai dengan ajaran Mo Tzu tentang kesesuaian raja dengan Surga, maka kehendak raja dengan kehendak surga adalah sama. Dengan demikian tidak akan terjadi bentrokan antara kehendak surga, kehendak raja, dan kehendak rakyat, karena rakyat juga harus menyesuaikan dengan raja. Setelah Tuhan, raja sebagai sumber terakhir segala ajaran dan ide-ide.

Beberapa pokok ajaran Mo Tzu tidak bertentangan dengan bagian yang lain, selalu ada hubungan dan kesesuaian dengan perbuatanperbuatan yang pernah dilakukan oleh raja-raja bijaksana zaman dahulu sebagai dasarnya. Dalam hal ini dapat dirumuskan dalam pola struktur sebagai berikut:

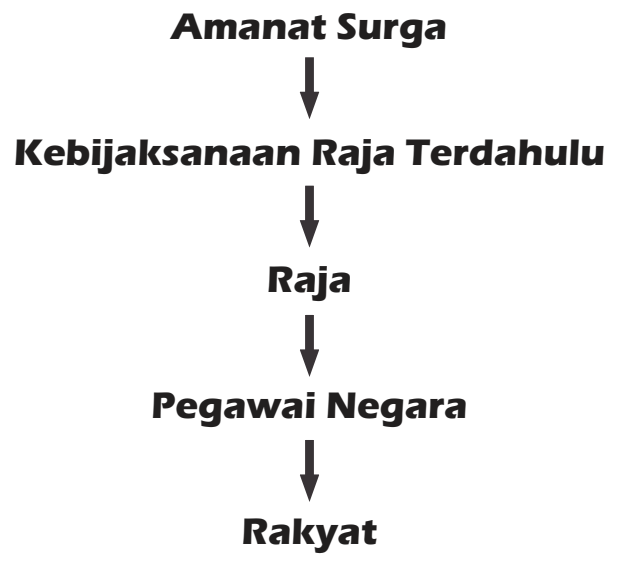

Pada pola terstruktur tersebut, jika setiap tingkatan sudah sesuai dengan tingkatan di atasnya maka memiliki nilai kebenaran. Semua raja harus sesuai dengan kehendak Surga, semua bangsawan dan pegawai kerajaan harus sesuai dengan kehendak raja. Mereka harus berpedoman kebijaksanaan raja terdahulu, begitu pula halnya dengan pegawai kerajaan. Selanjutnya rakyat harus tunduk dan sesuai dengan 
perintah pegawai kerajaan. Demikian argumentasi logis untuk mencapai kebenaran dalam rangka menciptakan ketertiban dan kebahagiaan.

\section{Prinsip verifikasi}

Suatu ajaran atau pendapat dinilai benar tidak hanya karena sesuai dengan ajaran atau pendapat yang menjadi dasarnya, tetapi juga adanya kesatuan dan kecocokan dengan pengalaman nyata (Edwards, 1952: 410). Suatu ajaran atau pendapat harus dapat diperiksa atau diuji kebenarannya dengan pengalaman langsung dari penglihatan dan pendengaran orang banyak.

Prinsip kasih semesta bagi Mo Tzu juga dapat dibuktikan secara nyata oleh masyarakat. Prinsip kasih semesta dapat mendatangkan keuntungan orang banyak, bukan hanya segolongan kecil masyarakat. Oleh karena itu kasih semesta adalah satu-satunya cara untuk mencapai kesejahteraan rakyat, dan mendekatkan kepada kebahagiaan serta menjauhkan kesengsaraan (Moore, 1946:40).

Untuk memperoleh pengetahuan yang benar orang seharusnya langsung membuktikan dengan kenyataan sesungguhnya yang diperoleh dengan alat pengetahuan, yaitu mata dan telinga dari rakyat banyak. Pengetahuan yang diperoleh secara langsung inilah yang merupakan ukuran apakah sesuatu itu benar. Jika sesuatu itu dapat didengar telinga dan dapat dilihat mata orang banyak, maka sesuatu itu dapat diterima sebagai sesuatu kebenaran. Sebaliknya jika sesuatu itu tidak dapat didengar dan tidak dapat dilihat, maka tidak dapat diterima sebagai suatu kebenaran. Dengan demikian Mo Tzu telah menggunakan metode empirisisme guna memeriksa kebenaran sesuatu (Northorp,1913: 364). Maka prinsip verifikasi harus dijalankan. Kebenaran harus berkorespondensi dengan kenyataan yang bisa dilihat.

\section{Sifat kegunaan}

Nilai kebenaran ditentukan oleh sifat kegunaan. Setiap nilai kebenaran dihubungkan dengan kesanggupannya untuk mendatangkan kesejahteraan dan menjauhkan kesengsaraan. Filsafat Mo Tzu termasuk paham kemanusiaan yang berlandaskan sifat kegunaan. Ajaran kasih semesta didasarkan atas pandangan utilitarianisme (Moore, 
1946: 263). Walaupun mendasarkan diri pada sifat kegunaan, agama tetap mempunyai peranan dalam ajarannya. Di dalam ajarannya tentang sanksi keagamaan, Tuhan menghendaki keadilan, tidak membeda-bedakan. Mempercayai Tuhan mempunyai manfaat, karena membantu mendatangkan kesejahteraan bagi rakyat.

Dalam kaitannya dengan nilai kebenaran, kitab Mohis telah menggariskan pedoman sebagai ukuran. Pedoman itu sebagai berikut:

"Kebenaran $(I)$ terkandung dalam tindakan yang memberi faedah. Kesetiaan (Chung) terkandung dalam perbuatan yang memberikan faedah bagi penguasa. Tatakrama yang baik (Hsiao) berarti memberikan keuntungan bagi orangtua" (Fung Yu Ian, 1953: 250).

Seseorang yang telah mengutamakan dan memberi kefaedahan bagi kepentingan umum dapat dinilai sebagai suatu kebenaran. Proses ke arah kebenaran dapat ditempuh dengan jalan menumbuhkan pemikiran untuk mencintai dunia dan menjadikan diri pribadi sebagai orang yang cakap untuk bertindak yang memberikan kefaedahan bagi dunia.

Telah disebutkan bahwa segala sesuatu harus berguna melatarbelakangi filsafat Mo Tzu. Hasil-hasil perbuatan harus dipertimbangkan dapat membawa keberuntungan atau kerugian. Termasuk juga menolak keberuntungan yang kecil untuk menghindari kerugian yang lebih besar atau menerima kerugian sekecil mungkin untuk memperoleh keuntungan terbesar. Dalam ajaran Mo Tzu semua argumen mengenai pokok pembahasan mempunyai latar belakang sifat kegunaan, segala sesuatu harus dapat menghasilkan faedah yang nyata (Moore, 1946: 151). Segala sesuatu yang bermanfaat dan berguna adalah keinginan Mo Tzu.

Mempercayai surga juga merupakan faedah. Surga menghendaki adanya keadilan, tidak membeda-bedakan. Mempercayai Surga membantu mendatangkan kemakmuran bagi rakyat. Dengan memberikan tekanan kepada kepentingan manusia banyak, tidak mementingkan individu dan golongan tertentu, ajaran Mo Tzu mempunyai dasar 
pandangan kasih yang tidak terbatas terhadap sesama manusia atau sifat yang tidak mementingkan diri sendiri (Fitzgerald, 1950: 98). Ternyata sifat kegunaan ini pun terlihat dalam pandangannya tentang hubungan manusia dengan Tuhan. Manusia mempunyai hubungan dengan Tuhan karena Tuhan akan mempunyai peranan di dalam kehidupan manusia, memberikan apa yang dikehendaki manusia. Jika manusia menurut kehendak Tuhan, maka Tuhan akan memberikan apa yang diinginkan manusia. Tuhan akan mengganjar kebaikan dan menghukum kejahatan yang dilakukan manusia.

Sifat pragmatik dari pandangan Mo Tzu juga terlihat pada sikapnya yang menolak tradisi upacara pemakaman jenazah dan perkabungan yang terlalu mewah dan lama. Sesuatu yang tidak mendatangkan kegunaan apalagi hanya merupakan pemborosan adalah suatu kesalahan besar. Oleh karena itu perkabungan yang lama dan upacara pemakaman yang mewah harus dihilangkan, karena merupakan tindakan pemborosan yang tidak bermanfaat bagi rakyat serta tidak akan membantu untuk mendekatkan rakyat kepada kemakmuran (Chan, 1973: 226). Dengan upacara pemakaman yang mewah dan perkabungan yang lama, orang tidak dapat melakukan tindakan-tindakan yang berguna. Jelaslah bahwa Mo Tzu lebih mementingkan azas kegunaan sebagai ukuran untuk menentukan kebenaran, maka sering disebut ajarannya bersifat utilitarianistik.

\section{TEORI KEBENARAN PANCASILA}

\section{Pancasila sebagai sistem ilmiah dan filsafat}

Sebelum membahas Pancasila sebagai sistem filsafat terlebih dahulu akan dikemukakan Pancasila sebagai sistem ilmiah. Bahwa sistem ilmiah harus memenuhi syarat-syarat, yakni: harus berobjek, bermetode, sistematik, dan kebenaran harus bersifat universal (Kaelan, 1995: 13-14). Syarat-syarat ilmiah yang dimiliki Pancasila akan dipaparkan berikutini.

Pancasila sebagai sistem ilmiah benar-benar merupakan suatu objek pembahasan, bahwa secara umum Pancasila adalah merupakan hasil budaya bangsa Indonesia. Oleh karena itu objek pembahasan 
Pancasila tidak dapat dilepaskan dengan objek material, yaitu bangsa Indonesia dan segala aspek pola budayanya. Atau dengan perkataan lain objek material Pancasila adalah segala unsur-unsur, nilai-nilai yang secara konkret tercermin pada bangsa Indonesia, berupa kepribadian, sifat, karakter, dan pola-pola budaya dalam rangka bermasyarakat, berbangsa, dan bernegara. Objek formal Pancasila adalah berupa pelaksanaan Pancasila dalam praktek kenegaraan secara resmi, segi yuridis kenegaraan.

Sistem ilmiah harus bermetode. Dalam hal ini metode merupakan suatu cara pendekatan dalam rangka pembahasan Pancasila, baik objek formal maupun material, sehingga mencapai kebenaran. Menurut Notonagoro, metode yang digunakan dalam pendekatan Pancasila adalah analitiko-sintesis. Dengan menganalisis objek tersebut diambil suatu sintesis untuk dapat merumuskan secara umum, sehingga dapat dipakai sebagai pedoman.

Pancasila sebagai sistem ilmiah juga bersifat sistematik. Suatu ilmu harus mempunyai suatu kesatuan yang bulat dan utuh. Kesatuan tersebut mempunyai bagian-bagian yang saling berhubungan, baik berupa hubungan interelasi maupun interdependensi. Secara keseluruhan jelas bahwa Pancasila membentuk suatu sistem, bahwa setiap sila tidak berdiri sendiri, terpisah antara sila yang satu dengan sila yang lain. Keseluruhan sila-sila merupakan suatu kebulatan yang utuh sebagai dasar negara. Walaupun Pancasila terdiri dari lima sila, tetapi sebagai suatu kesatuan tetap mengabdi pada tujuan yang satu, yakni kelima sila sebagai dasar negara dipakai untuk landasan mewujudkan masyarakat adil-makmur, material spiritual yang berdasarkan Pancasila.

Akhirnya Pancasila sebagai sistem ilmiah juga memiliki sifat kebenaran yang universal. Kebenaran suatu ilmu pengetahuan harus universal, artinya berlaku sembarang tempat, ruang, dan waktu. Sebenarnya hakikat kebenaran rumussan Pancasila adalah bersifat universal yaitu unsur-unsur Pancasila adalah bersifat abstrak, umum, dan universal. 
Sekarang akan dibahas mengenai Pancasila sebagai sistem filsafat. Suatu sistem filsafat harus memenuhi kriteria-kriteria sebagai berikut: objek filsafat bersifat menyeluruh artinya tidak tertentu, sistem filsafat harus bersifat koheren, metodenya bersifat mendasar atau sampai ke hakikatnya, dan kadar kebenarannya bersifat spekulatif. Atau dengan kata lain sistem filsafat itu merupakan suatu bagan konsepsional yang bersifat rasional yang mempunyai ciri-ciri bersifat menyeluruh, bersifat koheren, bersifat mendasar, dan bersifat spekulatif (Noor MS. Bakry, 1994).

Pancasila sebagai sistem filsafat merupakan bagan konsepsional. Menurut Kattsoff (1996: 7), konsepsi ini merupakan hasil generalisasi serta abstraksi dari pengalaman tentang hal-hal serta proses-proses satu demi satu. Pancasila juga merupakan abstraksi dari pengalaman dan perjalanan hidup bangsa Indonesia. Menurut Notonagoro, bahan Pancasila diambil dari adat kebiasaan, kebudayaan, dan agama-agama yang telah ada pada bangsa Indonesia (Suhadi, 1980: 12). Bagan konsepsional dalam sistem filsafat Pancasila ini juga bersifat rasional, yaitu bahwa antara masing-masing sila dalam Pancasila berhubungan secara logis.

Sistem filsafat harus bersifat menyeluruh. Sistem filsafat Pancasila di dalamnya telah tersusun suatu pola yang dapat mewadahi semua persoalan kehidupan dan menampung dinamika masyarakat. Pancasila sebagai sistem filsafat mempunyai objek menyeluruh, mencakup semua permasalahan hidup manusia, yakni: masalah hidup menghadapi diri sendiri, masalah hidup menghadapi sesama manusia, dan masalah hidup menghadapi Tuhan (Noor MS. Bakry, 1994: 14).

Sistem filsafat harus bersifat koheren. Bahwa bagan konsepsional tersebut berhubungan satu dengan yang lainnya secara runtut, tidak mengandung pernyataan-pernyataan yang saling bertentangan. Demikian pula dengan Pancasila, bagian-bagiannya saling melengkapi, setiap bagian-bagian mempunyai fungsi dan kedudukan tersendiri. Penjabaran nilai-nilai Pancasila juga bersifat runtut, tidak ada penjabaran Pancasila yang bertentangan dengan konsep dasar sebagai nilai-nilai diyakini kebenarannya. 
Metode dalam sistem filsafat mendasar, yakni mendalam sampai ke inti mutlak dari permasalahannya sehingga merupakan hal yang sangat fundamental. Pancasila sebagai sistem filsafat dirumuskan atas dasar inti mutlak tata kehidupan manusia di dalam rangka menghadapi diri sendiri, menghadapi sesama manusia, dan menghadapi Tuhan dalam bermasyarakat dan bernegara.

Sistem filsafat juga harus bersifat spekulatif, yakni merupakan hasil perenungan sebagai pra anggapan yang menjadi titik awal serta pangkal tolak pemikiran sesuatu hal. Sistem filsafat Pancasila pada permulaannya merupakan hasil pemikiran dari para tokoh kenegaraan yang merupakan suatu pola dasar sebagai titik awal yang kemudian dibuktikan kebenarannya.

Jelaslah bahwa sistem filsafat Pancasila bersifat koheren, dalam hubungan antarbagian-bagian dan pernyataan-pernyataannya. Bersifat menyeluruh, meliputi semua tata kehidupan manusia bermasyarakat dan bernegara. Bersifat mendasar, sampai ke inti mutlak tata kehidupan. Bersifat spekulatif, merupakan pra anggapan sebagai hasil perenungan pada awalnya.

Sistem filsafat Pancasila merupakan suatu bagan konsepsional. Menurut Kattsoff (1996: 7), konsep ini merupakan hasil generalisasi serta abstraksi dari pengalaman tentang hal-hal serta proses-proses satu demi satu. Pancasila juga merupakan abstraksi dari pengalaman dan perjalanan hidup bangsa Indonesia. Menurut Notonagoro, bahan Pancasila diambil dari adat kebiasaan, kebudayaan, dan agama-agama yang telah ada pada bangsa Indonesia (Suhadi, 1980: 12). Bagan konsepsional dalam sistem filsafat Pancasila ini juga bersifat rasional, yaitu bahwa antara masing-masing sila dalam Pancasila berhubungan secara logis.

Menurut Notonagoro pengertian hakikat abstrak ini dimungkinkan, bahkan seharusnya pada rumusan sila-sila Pancasila. Rumusan sila-sila Pancasila terdiri dari kata-kata pokok dan kata-kata sifat. Katakata pokoknya terdiri atas kata dasar, yaitu Tuhan, manusia, satu, rakyat, dan adil. Empat sila dibubuhkan awalan ke-an dan satu per-an, hal ini menjadikan abstrak kata dasarnya. Pengertian ini disebut penger- 
tian abstrak umum universal. Isinya sedikit, luasnya tidak terbatas. Artinya meliputi segala hal dan keadaan bangsa dan negara Indonesia dalam jangka waktu tidak terbatas (Sri Soeprapto, 1995: 31). Tuhan, manusia, satu, rakyat dan adil merupakan ada senyatanya. Sehingga ketuhanan, kemanusiaan, persatuan, kerakyatan, dan keadilan merupakan abstraksi serta generalisasi dari kenyataan yang sesungguhnya. Masing-masing abstraksi tersebut tidak terpisah-pisah, tetapi berhubungan secara logis sehingga bersifat rasional.

Objek filsafat bersifat menyeluruh. Sistem filsafat Pancasila dapat mewadahi semua permasalahan kehidupan dan menampung dinamika masyarakat. Menurut Notonagoro, antara bangsa Indonesia dengan Pancasila hubungan tidak dapat ditiadakan, disatu pihak landasan Pancasila sebagai sebabnya dan bangsa Indonesia sebagai akibatnya. Dengan demikian secara tegas dalam Pancasila tercermin pandangan bangsa Indonesia mengenai Tuhan, manusia, satu, rakyat, dan adil (Ali Mudhofir, 1996: 13). Dengan demikian, Pancasila memuat semua permasalahan manusia secara menyeluruh, yang meliputi: terhadap Tuhan, terhadap diri sendiri, dan terhadap yang ada di luar dirinya. Di sini pemikiran Notonagoro juga memenuhi kriteria sebagai sistem filsafat, karena juga bersifat menyeluruh, objeknya mencakup semua hal.

Mengenai sistem filsafat harus koheren, bahwa bagan konsepsional tersebut berhubungan satu dengan yang lainnya secara runtut. Tidak mengandung pernyataan-pernyataan yang saling bertentangan. Hubungan yang runtut dan koheren juga tercermin dalam susunan Pancasila yang menurut Notonagoro bersifat hierarkhis dan berbentuk piramidal.

Mengenai sistem filsafat Pancasila harus bersifat mendasar. Bahwa di dalam filsafat Pancasila dibahas sampai hal-hal yang mendasar, sampai ke hakikatnya sehingga sampai pada inti mutlaknya. Menurut Notonagoro hubungan antara negara Indonesia dengan landasan silasila Pancasila (yaitu: Tuhan, manusia, satu, rakyat, dan adil) merupakan hubungan kesesuaian yang merupakan keharusan. Maka arti dan isi setiap sila Pancasila adalah sebagai berikut: Ketuhanan ialah sifat- 
sifat dan keadaan negara yang sesuai dengan hakikat Tuhan; Kemanusiaan ialah sifat-sifat dan keadaan negara yang sesuai dengan hakikat manusia; Persatuan ialah sifat-sifat dan keadaan negara yang sesuai dengan hakikat satu; Kerakyatan ialah sifat-sifat dan keadaan negara yang sesuai dengan hakikat rakyat; Keadilan ialah sifat-sifat dan keadaan negara yang sesuai dengan hakikat adil. Menyimak hal ini, maka pembahasan filsafat Pancasila itu mengenai hal-hal yang mendasar, sampai kepada hakikatnya; hakikat Tuhan, manusia, satu, rakyat, dan adil.

Sistem filsafat juga harus bersifat spekulatif. Sistem filsafat merupakan hasil pemikiran yang masih merupakan pola dasar sebagai titik awal yang kemudian dibuktikan kebenarannya. Merupakan pra-anggapan sebagai hasil perenungan pada awalnya. Dalam filsafat Pancasila Notonagoro, hal ini menyangkut rumusan isi arti Pancasila yang kefilsafatan dari sila ke satu sampai sila ke lima. Relfeksi kefilsafatan yang dikembangkan Notonagoro untuk mengerti hakikat sila-sila Pancasila kemudian dijadikan pangkal tolak pengamalan objektif dan subjektif.

Dari uraian di atas jelaslah bahwa Pancasila memenuhi syarat sebagai sistem ilmiah dan sebagai sistem filsafat. Sehingga perlu digali lagi kemungkinan-kemungkinan sumbangan Pancasila bagi kemajuan dunia ilmiah dan kefilsafatan, terutama tentang teori kebenaran di dalamnya.

\section{Teori kebenaran koherensi, korespondensi, dan pragmatik}

Dalam sistem filsafat Pancasila mengandung tiga teori kebenaran, yakni: teori kebenaran koherensi, korespondensi dan pragmatik. Dengan demikian sistem filsafat Pancasila menjadi tangguh jika dibandingkan dengan sistem filsafat yang lain. Diharapkan juga menjadi sistem filsafat yang lebih lengkap jika dibandingkan dengan sistem filsafat yang lain. Pada uraian berikut ini akan dipaparkan tiga teori kebenaran yang terdapat dalam sistem filsafat Pancasila.

Pertama, teori korespondensi. Bagi teori kebenaran ini, pernyataan benar jika pernyataan bersifat konsisten dengan pernyataan-per- 
nyataan sebelumnya yang dianggap benar. Menurut Notonagoro (1975: 19). Pancasila dasar filsafat negara merupakan satu kesatuan, tersusun atas bagian-bagian, tetapi bagian-bagian itu tidak saling bertentangan. Semuanya menyusun hal yang baru dan utuh. Tiap-tiap bagian Pancasila merupakan bagian yang mutlak, jika dihilangkan satu bagian saja hilanglah halnya, sebaliknya terlepas dari halnya, bagian-bagian tersebut dihilangkan kedudukan dan fungsinya. Selain daripada itu setiap sila dari Pancasila di dalamnya mengandung silasila lainnya. Terdapat hubungan yang saling mengkualifikasi. Ketuhanan Yang Maha Esa adalah ketuhanan yang berkemanusiaan, berpersatuan, berkerakyatan, dan berkeadilan. Begitu seterusnya dengan sila-sila yang lain pula. Hubungan satu kesatuan dengan sila lainnya, hubungan sila ke satu sampai sila ke lima bersifat runtut. Inilah suatu penerapan teori koherensi.

Hubungan logis secara pengakuan atau cerminan teori koherensi terlihat pada susunan Pancasila yang menurut Notonagoro bersifat hierarkhis dan berbentuk piramidal (Suhadi, 1980: 14). Artinya kelima sila dari Pancasila itu menunjukkan suatu rangkaian yang bertingkat, sehingga tidak boleh dibolak-balik tata urutannya. Hal ini juga menunjukkan rangkaian tingkat dalam luas dan isi sifatnya. Setiap sila yang ada dibelakangnya lebih sempit cakupannya tetapi lebih banyak isi sifatnya. Sebagai contoh, misalnya rumusan hirarkhis piramidal sila yang ke-3. Persatuan Indonesia dilandasi oleh Ketuhanan Yang Maha Esa, dan Kemanusiaan yang adil dan beradab serta melandasi Kerakyatan yang dipimpin oleh hikmat kebijaksanaan dalam permusyawarahan/perwakilan dan Keadilan sosial bagi seluruh rakyat Indonesia.

Selain dari pada itu hubungan konsistensi ini terlihat pada Pancasila sebagai aksioma kemudian diturunkan ke empat pokok pikiran sebagai teorema-teorema, dan selanjutnya diturunkan ke pasal-pasal UUD 1945. Dalam penjabaran ini telah terbukti bahwa pasal-pasal UUD 1945 konsisten dengan empat pokok pikiran, dan empat pokok pikiran konsisten dengan Pancasila (Noor MS. Bakry, 1994: 47). Jelaslah bahwa sistem filsafat Pancasila mengakui dan menerapkan teori kebe- 
naran koherensi. Di dalam sistem filsafat Pancasila terdapat teori kebenaran koherensi.

Kedua, teori korespondensi. Menurut teori korespondensi ini, suatu pernyataan benar jika materi pengetahuan yang dikandung pernyataan itu berhubungan dengan objek yang dituju oleh pernyataan tersebut. Sistem filsafat Pancasila dinyatakan sebagai jiwa bangsa Indonesia, berkepribadian bangsa Indonesia, pandangan hidup bangsa dan pedoman hidup bangsa. Hal ini benar jika sesuai dengan kenyataan sehari-hari (Noor MS. Bakry, 1994: 49). Hal ini tepat pendapat Notonagoro (1975: 17), bahwa bangsa Indonesia ber-Pancasila dalam triprakara, yakni Pancasila adat kebudayaan, religius, dan kenegaraan. Kenyataan ini bisa dilihat dalam dinamika hidup sehari-hari masyarakat dan bangsa Indonesia.

Teori tri-prakara tersebut menunjukkan bahwa bangsa Indonesia ber-Pancasila dalam asas kultural, asas religius, dan asas kenegaraan. Dengan demikian kebenaran nilai-nilai Pancasila diukur dari kesesuaiannya dengan kenyataan baik di bidang kultur, religi, dan kenegaraan. Kebenaran harus berkorespondensi dengan kenyataan tersebut.

Isi arti Pancasila yang abstrak umum universal dapat menjadi sumber landasan pemecahan masalah kenyataan hidup sehari-hari. Menurut Notonagoro, ada hubungan yang mutlak antara Pancasila dengan bangsa Indonesia, yaitu hubungan sebab akibat (Sri Soeprapto, 1994: 53). Segala sesuatu mulai dari kepribadian bangsa dan kehidupan bermasyarakat harus sesuai dengan hakikat yang terdapat dalam sebabnya. Maka kebenaran menurut sistem filsafat Pancasila, bahwa kandungan pernyataan-pernyataan dari sila-sila Pancasila harus cocok, sesuai, terjelma dalam keadaan senyatanya bermasyarakat dan bernegara. Sila-sila dalam Pancasila berkesuaian atau berkorespondensi dengan objek yang dituju.

Ketiga, teori pragmatik. Menurut teori ini, nilai kebenaran suatu proposisi diukur dengan kriteria apakah proposisi tersebut berfungsi dalam kehidupan praktis atau tidak. Teori ini tercermin dalam Pancasila sebagai pemersatu bangsa Indonesia. Hal ini memang menunjukkan bahwa sistem filsafat Pancasila berfungsi secara praktis. Fakta sejarah telah membuktikan baik sejak proses penetapan Pancasila sebagai 
dasar negara maupun dalam menghadapi pemberontakan-pemberontakan, dengan jiwa Pancasila ini persatuan dan kesatuan tetap terjaga (Noor MS. Bakry, 1994: 49). Para penganut Pancasila percaya akan kebenaran Pancasila, karena Pancasila bersifat fungsional dalam mempersatukan bangsa Indonesia.

Jika dilihat dari segi historis, Pancasila juga memiliki fungsi praktis. Hal ini karena Pancasila merupakan jawaban atas pertanyaan esensial dalam sidang BPUPKI dan PPKI: "Jika negara kita merdeka, maka apa dasarnya?", apa landasan yang mau dipakai. Analisis empat kausalitas Aristoteles dari Notonagoro kiranya membuktikan fungsi praktis ini. Salah satu relasi kausalitas tersebut adalah kausa finalis. Kausa finalis Pancasila adalah sebagai dasar kefilsafatan negara atau dasar negara Indonesia merdeka. Proposisi-proposisi dalam sistem filsafat Pancasila terlihat kemanfaatannya sebagai dasar negara Indonesia, bukan hanya proposisi yang koheren dan koresponden dengan kenyataan saja.

Selengkapnya analisis teori kausalitas Aristoteles terhadap Pancasila adalah sebagai berikut. Bahwa di dalam Pancasila atau terjadinya Pancasila ada empat kausa, yakni: kausa materialis atau sebab berupa bahan, kausa formalis berupa bentuk, kausa efisien atau sebab berupa kerja, dan kausa finalis atau sebab berupa tujuan. kausa materialis Pancasila adalah nilai-nilai kebudayaan bangsa Indonesia. Kausa formalisnya adalah bentuk susunan Pancasila dalam alinea keempat Pembukaan Undang-undang Dasar 1945. Kausa efisiennya adalah kerja BPUPKI dan PPKI ketika merumuskan Pancasila dan menetapkan Pancasila dalam kelas Pembukaan Undang-undang Dasar 1945. Kausa finalisnya adalah sebagai Dasar Negara.

Pancasila sebagai asas persatuan dan kesatuan, di dalam diri Pancasila juga mengandung persatuan dan kesatuan. Jika di dalam diri Pancasila mengandung tiga teori kebenaran: koherensi, korespondensi, dan pragmatik; maka konsekuensinya menurut Pancasila pernyataan atau proposisi benar jika runtut, konsisten, sesuai dengan kenyataan dan sekaligus membawa kefaedahan. Ketiga teori tersebut menurut Pancasila tidak dipertentangkan tetapi saling melengkapi. Dalam hal saling melengkapi itu, mengikuti asas hierarkhis-piramidal dan saling 
mengkualifikasi dalam Pancasila dengan urutan: koherensi, korespondensi, dan pragmatik.

\section{PENGEMBANGAN ILMU PENGETAHUAN DI INDONESIA}

\section{Komparasi teori kebenaran Mo Tzu dan Pancasila}

Dalam komparasi ini akan dicari dan dianalisis kesamaan-kesamaan dan perbedaan-perbedaan antara teori kebenaran Mo Tzu dan Pancasila. Kemudian akan dirumuskan kelebihan teori kebenaran Pancasila, selanjutnya mencari relevansinya bagi pengembangan ilmu pengetahuan di Indonesia.

Baik teori kebenaran Mo Tzu maupun teori kebenaran Pancasila sama-sama melandaskan diri pada paham koherensi, korespondensi, dan pragmatis. Bahwa kebenaran bukan hanya semata-mata kesesuaian antara berbagai pernyataan, tetapi juga harus ada kesesuaian atau korespondensi antara pernyataan dan kenyataan yang bisa diverifikasi dengan indera. Di samping itu kebenaran haruslah mengandung kefaedahan atau kegunaan.

Dalam teori kebenaran Mo Tzu dan teori kebenaran Pancasila keduanya sama-sama menjunjung tinggi nilai-nilai religius. Dalam hal ini Mo Tzu pernah mengatakan sebagai berikut.

"Putra Surga (kaisar) adalah orang yang terhormat dan terkaya di dunia. Siapapun yang berdoa memohon kekayaan dan kehormatan tidak dapat tidak harus mematuhi kehendak langit. Mereka yang patuh terhadap kehendak langit, mengasihi secara universal dan keuntungan orang-orang lain, serta mensyukuri keberuntungan orang lain akan dihormati. Mereka yang melanggar hukum langit yang bersikap tidak bersahabat dan merugikan orang lain akan dirugikan secara setimpal. Dengan demikian siapa yang patuh akan diberi pahala dan siapa yang menentang akan diberi hukuman" (Fung Yu Lan, 1953: 96).

Dengan argumen tersebut Mo Tzu hendak menjelaskan kepada manusia tentang keberadaan kekuasaan supranatural serta hukumhukumnya yang tidak bisa dibantah oleh manusia sebagai dasar kebe- 
naran. Dalam sistem hierarkhis-piramidal Pancasila, nilai ketuhanan memiliki hierarkhi yang tertinggi. Karena itu nilai ketuhanan harus mendasari dan menjiwai nilai-nilai yang lain. Nilai ketuhanan menjadi sumber bagi suatu kebenaran.

Teori kebenaran Mo Tzu dan teori kebenaran Pancasila samasama menaruh hormat pada "orangtua". Pada Mo Tzu memandang Raja Yao, Shun, dan Yu dihormati sebagai sumber kebenaran karena telah menjalankan Chien ai atau kasih semesta sebagaimana Tuhan jalankan. Sementara itu pada Pancasila menghargai para pendiri bangsa/founding fathers terutama para perumus nilai-nilai Pancasila dalam sidang-sidang BPUPKI dan PPKI.

Berkaitan dengan perbedaan dari dua teori tersebut, teori kebenaran Mo Tzu didasari dan dijiwai oleh filsafat Chien ai atau kasih semesta. Sementara kebenaran Pancasila didasari dan dijiwai oleh nilai-nilai Pancasila sebagai suatu sistem. Baik sistem hierarkhis-piramidal maupun sistem mengkualifikasi. Sistem hierarkhis-piramidal dalam Pancasila artinya kelima sila dari Pancasila itu menunjukkan suatu rangkaian bertingkat yang tidak boleh dibolak-balik. Hal ini juga mewujudkan rangkaian tingkat dalam luas dan isi sifatnya. Setiap sila yang ada di belakang sila lainnya lebih sempit cakupannya tetapi lebih banyak isi sifatnya (Suhadi, 1980: 14). Sedangkan sistem mengkualifikasi dalam Pancasila berarti kelima sila dalam saling berhubungan, setiap sila atau nilai mengandung sila atau nilai yang lain.

Dalam teori kebenaran Mo Tzu lebih menitikberatkan pada teori kebenaran pragmatik. Bagi Mo Tzu nilai kebenaran sangat ditentukan oleh sifat kegunaan atau kefaedahannya. Setiap nilai dihubungkan dengan kesanggupannya dan kegunaannya untuk mendatangkan kesejahteraan dan menjauhkan kesengsaraan. Kesejahteraan umum yang dicita-citakan Mo Tzu adalah memperjuangkan kemakmuran dan kepadatan penduduk. Ajaran Chien ai atau universal love (kasih semesta) didasarkan atas pandangan utilitarianisme (Moore, 1946: 263). Dalam teori kebenaran Pancasila ketiga teori tersebut digunakan keseluruhan secara berimbang, tidak hanya menitikberatkan pada salah satu saja.

Pada teori kebenaran Mo Tzu, Tuhan dipakai sebagai dasar kebenaran sepanjang berfaedah saja. Pada teori kebenaran Pancasila, nilai- 
nilai ketuhanan harus mampu mendasari dan menjiwai pada segi-segi korespondensi dan pragmatis. Nilai ketuhanan bersumber pada adanya Tuhan sebagai suatu kenyataan, bukan sekedar karena membawa manfaat atau kegunaan saja.

Kemunculan teori kebenaran Mo Tzu dilatarbelakangi oleh kondisi negara-negara yang saling berperang guna menciptakan suatu perdamaian. Maka ditawarkanlah prinsip Chien ai atau kasih semesta dengan teori kebenarannya. Adanya kekacauan di atas dunia disebabkan karena orang tidak menjalankan kasih semesta sebagai prinsip hidup. Orang masih melaksanakan kasih yang membeda-bedakan antara yang satu dengan yang lain, diskriminasi adalah penyebab utama adanya kesengsaraan di dunia. Segala sesuatu yang berpusat kepentingan sendiri dan membeda-bedakan akan membawa kekacauan. Untuk mengembalikan kepada ketertiban, kasih yang membeda-bedakan atau pilih kasih harus dikembalikan kepada kasih semesta. Pelaksanaan kasih semesta akan membawa kebahagiaan dan menunjukkan dasar perbuatan yang menyeluruh. Sifat menyeluruh sesuai dengan sifat Tuhan yang mengasihi manusia tanpa membeda-bedakan. Mo Tzu berpendapat bahwa kasih semesta adalah suatu jalan yang harus ditempuh oleh manusia (Edwards, 1952: 410). Sementara pada Pancasila kemunculannya dilatarbelakangi oleh penjajahan guna menciptakan dasar negara yang merdeka dan mengisi kemerdekaan. Oleh karena itu, diharapkan ada relevansinya bagi pembangunan negara, tidak terkecuali di bidang pengembangan ilmu pengetahuan di Indonesia.

Pada teori kebenaran Mo Tzu, yaitu teori kebenaran koherensi, korespondensi, dan pragmatik pada dasarnya untuk memperkuat filsafat chien ai. Jadi, teori kebenaran Mo Tzu untuk membenarkan filsafat chien ai. Pada Pancasila, justru teori kebenarannya melandaskan pada nilai-nilai Pancasila yang diharapkan bisa berperan dalam kehidupan bermasyarakat, berbangsa, dan bernegara.

Dari komparasi di atas dapatlah dirumuskan bahwa bagi Pancasila kebenaran ilmiah harus koheren dengan nilai-nilai ketuhanan, kemanusiaan, persatuan, kerakyatan, dan keadilan, harus berkorespondensi sesuai dengan kenyataan adanya Tuhan, manusia, ratu, rakyat, dan adil, serta secara pragmatik ukuran kegunaan harus dikem- 
balikan pada kemanusiaan yang berketuhanan, berpersatuan, berkerakyatan, dan berkeadilan.

Tiga teori kebenaran yakni koherensi, korespondensi, dan pragmatik dalam Pancasila tidak saling dipertentangkan, tetapi saling melengkapi. Dalam hal saling melengkapi, mengikuti sistem hierarkhispiramidal dan saling mengkualifikasi dengan tata urut: koherensi, korespondensi, dan pragmatik. Jadi dalam Pancasila bukan sekedar azas kegunaan semata atau utilitarianistik saja seperti dalam Mo Tzu.

\section{Kebenaran ilmu pengetahuan}

Kebenaran ilmu pengetahuan muncul dari hasil penelitian ilmiah. Melalui metode ilmiah yang telah baku sesuai dari sifat dasar dari masing-masing ilmu dihasilkanlah teori ilmiah yang telah teruji kebenarannya. Setiap ilmu pengetahuan secara tegas menetapkan jenis objek secara ketat apakah objek itu bersifat abstrak atau konkret sesuai dengan sikap ontologis yang mendasarinya, serta menetapkan langkah-langkah ilmiah sesuai dengan objek khas yang dihadapi (Abbas Hamami Mintaredja, 1997: 24). Mengacu pada status ontologis objek, maka pada dasarnya kebenaran dalam ilmu pengetahuan dapat digolongkan dalam dua jenis teori kebenaran korespondensi dan teori kebenaran koherensi. Ilmu-ilmu kealaman pada umumnya menuntut kebenaran korespondensi, karena fakta-fakta objektif dituntut dalam pembuktian terhadap proposisi, tetapi juga tidak terlepas sama sekali tetapi teori koherensi misalnya dari perumusan masalah sampai hipotesis. Akan tetapi berbeda dengan ilmu-ilmu kemanusiaan, ilmu sosial, sejarah. Ilmu-ilmu ini menuntut koherensi di antara proposisi-proposisi, tetapi juga tidak dapat melepaskan secara bebas begitu saja teori kebenaran korespondensi.

Kebenaran ilmiah walaupun bersifat universal, tetapi juga relatif. Karena sifat kebenaran ilmiah itu merupakan terminal. Artinya jika suatu saat dihasilkan penemuan baru atau teori baru, maka teori lama telah dianggap gugur. Dengan demikian kebenaran ilmiah juga dihadapkan pada prospek ilmu. Bahwa setiap ilmu selain untuk mencapai kebenaran yang objektif, juga selalu memperhitungkan masa depan. 
Perhitungannya adalah tentang kemungkinan-kemungkinan yang terjadi yang berupa perkembangan, baik berupa penyempurnaan maupun melengkapi teori-teori yang sudah ada, bahkan mungkin mengganti dengan teori yang baru sama sekali.

Kelebihan ilmu terletak pada ketersusunannya secara logis dan sistematis serta telah teruji kebenarannya. Melalui beberapa langkah dalam metode keilmuan, dari perumusan masalah sampai penemuan teori ilmiah, ilmu berhasil menetapkan tentang kebenaran ilmiah. Pada dasarnya kebenaran dalam ilmu pengetahuan meliputi dua jenis teori kebenaran, yaitu koherensi dan korespondensi. Teori koherensi tampak dalam langkah metode ilmiah: dari penentuan masalah, penetapan kerangka masalah, dan hipotesis. Teori korespondensi tampak dalam angka metode ilmiahnya selanjutnya, yakni: verifikasi hipotesis sampai pada teori ilmiah.

Namun, atas dasar kelebihan ilmu seperti yang telah diuraikan di atas, masih juga terdapat berbagai kekurangan ilmu pengetahuan. Kekurangan-kekurangan ini bersumber pada asumsi landasan epistemologi ilmu, yang menyatakan bahwa manusia mampu memperoleh pengetahuan yang bertumpu pada persepsi, ingatan dan penalaran, berpikir secara rasional dan empiris dengan teori koherensi dan korespondensi. Persepsi yang mengandalkan panca indera jelas ada kelemahannya, karena panca indera tidak sempurna. Demikian juga ingatan kurang dapat dipercaya, begitu juga mengandalkan penalaran dari rasio semata juga jelas mempunyai kelemahan untuk mencapai kebenaran (Jujun Suriasumantri, 1981:17).

Penjelajahan ilmu pengetahuan untuk mencapai kebenaran hanya membatasi gejala-gejala empiris. Tetapi sebenarnya aspek kehidupan secara keseluruhan bersifat kompleks dan tidak semata-mata bersifat empiris. Menurut Jujun (1981: 18), manusia perlu berpaling kepada metode-metode lain, teori-teori lain. Bahkan dalam ruang lingkup empiris ini masih banyak segi-segi kehidupan yang belum terjangkau.

Manusia tidak pernah puas terhadap pengetahuan yang telah diperolehnya dalam arti pengetahuan sehari-hari tidak membawa perubahan yang besar. Dengan demikian, manusia hanya merasa bahwa 
pengetahuan adalah sub kelas dari kepercayaan yang benar dan selalu benar. Oleh karena itu manusia ingin mencari kepuasan melalui pembahasan yang lebih mendalam terhadap adanya gejala yang ajeg. Dalam hal ini manusia merasa bahwa ilmu pengetahuan adalah sesuatu yang merupakan hasil usaha manusia untuk meperadab dirinya (Abbas Hamami Mintaredja, 1983: 65). Dalam rangka memenuhi hasrat ingin tahunya, manusia merasa bahwa dengan ilmu pengetahuan akan memperoleh kebenaran yang lebih meyakinkan daripada kebenaran lewat pengatahuan biasa saja.

Dari uraian yang telah dipaparkan di atas tampak bahwa, sesungguhnya dalam penjelajahan manusia dalam mencari suatu kebenaran secara ilmiah ternyata masih berada dalam tahap awal sekali. Maka komparasi teori kebenaran Mo Tzu dan Pancasila yang telah dipaparkan di atas kiranya menemukan relevansinya dalam menyumbangkan gagasan ilmu pengetahuan dalam rangka menggapai kebenaran.

\section{RELEVANSI KOMPARASI TEORI KEBENARAN BAGI PENGEMBANGAN ILMU PENGETAHUAN}

Setelah dilakukan analisis komparatif seperti telah dilakukan di atas, ternyata antara teori kebenaran Mo Tzu dan teori kebenaran Pancasila ada beberapa kesamaan dan perbedaan. Kesamaan tersebut adalah: keduanya sama-sama menggunakan paham koherensi, korespondensi dan pragmatik, sama-sama menjunjung tinggi nilai religius dan sama-sama menunjukkan hormat pada orang tua.

Walaupun demikian jika dilihat dari segi perbedaannya, kiranya teori kebenaran Pancasila lebih lengkap dalam perannya bagi pengembangan ilmu pengatahuan, lebih khusus lagi di Indonesia. Teori kebenaran Mo Tzu berlandaskan pada nilai-nilai chien ai atau cinta kasih universal. Teori kebenaran Pancasila berlandaskan pada nilai-nilai Pancasila. Di sinilah relevansi teori kebenaran Pancasila, bahwa pengembangan ilmu di Indonesia tidak boleh melupakan, bahkan selalu mendasarkan pada nilai-nilai Pancasila.

Teori kebenaran Mo Tzu walaupun menggunakan tiga paham koherensi, korespondensi, dan pragmatik tetapi lebih menitikberatkan pada pragmatik. Bagi teori kebenaran Pancasila ketiga paham tersebut 
digunakan secara berimbang. Relevansinya bahwa, pengembangan ilmu pengetahuan di Indonesia harus koheren dengan nilai-nilai ketuhanan, kemanusiaan, persatuan, kerakyatan, dan keadilan. Ilmu pengetahuan di Indonesia harus koresponden/sesuai dengan kenyataan adanya Tuhan, manusia, ratu, rakyat, dan adil. Di samping itu, pengembangan ilmu pengetahuan di Indonesia harus berfaedah bagi kemanusiaan yang berketuhanan, berpersatuan, berkerakyatan dan berkeadilan.

Dalam teori kebenaran Mo Tzu memang tidak melupakan nilai religius, tetapi Tuhan diikutsertakan dalam teorinya karena membawa faedah. Bagi teori kebenaran Pancasila, Tuhan dipandang benar-benar nyata. Dengan demikian seharusnya pengembangan ilmu pengetahuan di Indonesia Tuhan dipandang sebagai sumber nilai. Bahkan nilai ketuhanan harus bisa mendasari dan menjiwai nilai-nilai kemanusiaan, persatuan, kerakyatan, dan keadilan.

Latar belakang munculnya teori kebenaran Mo Tzu adalah kondisi perang di Cina guna memunculkan perdamaian dan sekaligus untuk membenarkan filsafat chien ai atau kasih semesta. Sementara munculnya Pancasila dilatarbelakangi oleh penjajahan untuk memunculkan dasar negara yang merdeka dan mengisi kemerdekaan. Maka teori kebenaran Pancasila harus menjadi pengawal dalam pengembangan ilmu pengetahuan di Indonesia terutama di era kemerdekaan ini. Di Indonesia, ketiga paham yakni: koherensi, korespondensi, dan pragmatik harus saling melengkapi. Dalam saling melengkapi tersebut harus mengikuti sistem hierarkhis-piramidal dan sistem mengkualifikasi dengan tata urutan: koherensi, korespondensi, dan pragmatik.

Jika Pancasila benar-benar dipakai sebagai suatu dasar filsafat, maka pengembangan ilmu pengetahuan di Indonesia bukan sekedar sesuatu yang ditempelkan dari luar. Pengembangan ilmu pengetahuan di Indonesia harus dikawal dengan teori kebenaran Pancasila, yang relevansinya sudah dikemukakan di atas.

\section{SIMPULAN}

Berdasarkan uraian-uraian yang telah dipaparkan maka dapat diambil beberapa kesimpulan sebagai berikut: 
1. Teori kebenaran Mo Tzu menggunakan tiga paham yakni: koherensi, korespondensi, dan pragmatik. Dari ketiga paham ini Mo Tzu lebih menitikberatkan pada paham pragmatik, maka filsafatnya sering disebut bersifat utilitarianistik. Sesuatu dianggap benar jika berguna atau berfaedah.

2. Teori kebenaran Pancasila menggunakan tiga paham yakni: koherensi, korespondensi, dan pragmatik. Ketiga paham ini saling melengkapi.

3. Hasil komparasi menunjukkan kesamaan bahwa teori kebenaran Mo Tzu dan Pancasila sama-sama menggunakan tiga paham koherensi, korespondensi, dan pragmatik. Keduanya sama-sama menjunjung tinggi nilai-nilai religius. Keduanya juga menaruh hormat pada orangtua atau para pendahulu.

4. Perbedaan teori kebenaran Mo Tzu dan Pancasila dapat dikemukakan sebagai berikut:

a. Teori kebenaran Mo Tzu didasarkan pada filsafat chien ai atau kasih semesta. Teori kebenaran Pancasila di dasarkan pada nilainilai Pancasila.

b. Teori kebenaran Mo Tzu telah menitikberatkan pada paham pragmatik. Teori kebenaran Pancasila menggunakan paham koherensi, korespondensi, dan pragmatik yang saling melengkapi.

c. Teori kebenaran Mo Tzu memandang Tuhan sebagai sesuatu yang berfaedah saja. Dalam Pancasila Tuhan dipandang benarbenar nyata adanya.

d. Latar belakang teori kebenaran Mo Tzu adalah peperangan guna mewujudkan perdamaian. Dalam Pancasila latar belakangnya penjajahan guna mewujudkan dasar negara yang merdeka.

e. Teori kebenaran Mo Tzu untuk membenarkan filsafat chien ai. Teori kebenaran Pancasila diharapkan berperan dalam kehidupan masyarakat dan negara.

Relevansi bagi pengembangan ilmu pengetahuan di Indonesia. Bahwa kebenaran ilmiah harus koheren dengan nilai-nilai ketuhanan, kemanusiaan, persatuan, kerakyatan, dan keadilan. Kebenaran ilmiah 
juga harus berkoresponden dengan kenyataan adanya Tuhan, manusia, ratu, rakyat, dan adil. Di samping itu kebenaran ilmiah juga harus berguna bagi kemanusiaan yang berketuhanan, berpersatuan, berkerakyatan, dan berkeadilan.

\section{DAFTAR PUSTAKA}

Abbas H.M., 1977, Beberapa Masalah Pokok Mengenai Pengetahuan (Suatu Probleme Falsafi), Yayasan Pembinaan Fakultas Filsafat UGM, Yogyakarta.

1983, Epistemologi, Fakultas Filsafat UGM, Yogyakarta.

Ali Mudhofir, 1996, Garis Besar Filsafat, Fakultas Filsafat UGM, Yogyakarta.

Bakker, A dan A. Charris Zubair, 1990, Metodologi Penelitian Filsafat, Fakultas Filsafat UGM, Yogyakarta.

Chan, W.T., 1973, A Source Books in Chinese Philosophy, Princeton Press, Princeton.

Cheng, Tien Hsi, 1947, China Moulded by Confusius, Stevens \& Sons Limeted, London.

Creel,H,G., 1953, Chinese Thought From Confucius to Mao Tse Tsung, The University of Chicago, Chicago.

Edwards, Paul, 1952, The Encyclopedia of Philosophy, Skettington \& Son Ltd., New York.

Endang Saifudin Anshori, 1987, Ilmu, Filsafat dan Agama, Bina Ilmu, Surabaya.

Fitzgerald, C.P., 1950, China A Short Cultural History, The Cresset Press, London.

Fung Yu Lan, 1953, A History of Chinese Philosophy Vol. I, Princeton Press, Princeton.

Jujun Suriasumantri, 1981, "Tentang Hakikat Ilmu: Sebuah Pengantar

Redaksi" dalam Jujun Suriasumantri, Ilmu Dalam Perspektif, Yayasan Obor Indonesia, Jakarta.

Kaelan, 1995, Pancasila Yuridis Kenegaraan, Paradigma, Yogyakarta.

Kattsoff, Louis O., Element of Philosophy, Alih Bahasa Soejono Soemargono Pengantar Filsafat, Tiara Wacana, Yogyakarta. 
Moore, Charles A., 1946, Philosophy Eas and West, Princeton University Press, New Jersey.

Noor MS. Bakry, 1994, Orientasi Filsafat Pancasila, Liberty, Yogyakarta.

Northorp, F.S.C., 1913, The Metting of of East and West, The Macmillan Company, New York.

Notonagoro,1975, Pancasila Secara Ilmiah Populer, Pantjuran Tujuh, Jakarta.

Peursen, C.A. Van, 1983, Filosofische Orientatik, diterjemahkan Dick Hartoko, Orientasi di Alam Filsafat, PT. Gramedia, Jakarta.

Sidi Gazalbu, 1981, Sistematika Filsafat, Buku II, Bulan Bintang, Jakarta.

Soejono, Soemarjono, 1983 a, "Ilmu Pengetahuan dan Kebenaran" dalam Tim Fakultas Filsafat UGM, Yogyakarta.

karta. 1983 b, Filsafat Ilmu Pengetahuan, Nur Cahaya, Yogya-

Sri Soeprapto, 1994, Hand Out Filsafat Pancasila, Program Studi Ilmu Filsafat Program Pasca Sarjana UGM, Yogyakarta. 1995, "Aktulisasi nilai-nilai Filsafat Pancasila Notonagoro", dalam Jurnal Filsafat, seri 22 Agustus 1956.

Suhadi, 1980, Pafili, Tiga serangkai, Tiga Serangkai, Solo. 